\title{
A relação turismo e imagem na gastronomia paraense
}

\author{
Cássia Araújo Mareco* Ligia T. Lopes Simonian**
}

Núcleo de Altos Estudos Amazônicos - NAEA (Brasil)

\begin{abstract}
Resumo: Entender a relação que a imagem fotográfica possui com o turismo foi o norte que orientou este artigo. Ao ter-se a gastronomia paraense como foco da análise, percebe-se a mesma como uma das mais genuínas do país, principalmente por sua relação direta com os recursos naturais da floresta amazônica. Vincularam-se referenciais bibliográficos que abordam o turismo, a imagem e a gastronomia. $\mathrm{E}$ com base nesses tópicos se realizaram duas pesquisas de campo, uma de caráter qualitativo e outra de cunho quantitativo. Dentre os resultados obtidos, revelaram-se a importância de imagens como recurso da promoção da gastronomia paraense e que a maioria dos turistas não teve acesso às imagens fotográficas da gastronomia paraense antes da chegada á Belém, embora a fotografia gastronômica seja muito valorizada pelas empresas entrevistadas neste trabalho.
\end{abstract}

Palavras-chave: Fotografia; Turismo; Gastronomia; Belém/Pará.

\section{The relationship tourism and image in the gastronomy of Para}

Abstract: To understand the existing relationships between photographic image and tourism was the purpose of this academic work, and the gastronomy of Para was chosen as the focus. The Para gastronomy is considered as one of the most genuine in Brazil mainly on account of its direct links to its roots, the natural resources of Amazon Region. The literature with respect to tourism, image and gastronomy have been reviewed and research of a qualitative and quantitative nature carried out in line with the major findings of this analysis. Among the most highlighted results, the importance of images as a promotional resource for Pará gastronomy was underscored as it was revealed that most tourists had no previous access to photographic images of the Pará gastronomy before their arrival in Belém although images of gastronomy are highly esteemed by the companies interviewed.

Keywords: Photography; Tourism; Gastronomy; Belem/Para.

\section{Introdução}

Tem-se visto com frequência a utilização de fotografias em promoções de produtos turísticos. Principalmente, por meio da internet, revistas, jornais, folders e por turistas, que as mostram para amigos e parentes. Como objeto de estudo, definiu-se a circulação de imagens referentes à gastronomia do Pará e, consequentemente, a importância de tais imagens fotográficas para a cultura amazônica e promoção turística.

A culinária do ser humano amazônico se construiu, basicamente, por pratos indígenas, e é constituída de elementos oriundos da própria natureza. Assim, essa cozinha é vista a partir da singularidade em sua estrutura étnica e pela composição bastante orgânica (Orico, 1972). Nesse cenário, entre as peculiaridades dessa gastronomia, questionou-se se imagens da culinária paraense fazem, eficientemente, parte da divulgação da cultura local por empresas privadas e instituições públicas, e qual a importância que elas representam para estes estabelecimentos.

Para tanto, fez-se, primeiramente, o levantamento teórico acerca do turismo, da fotografia e de suas implicações no turismo, dos aspectos culturais da gastronomia brasileira e a caracterização da área sob a perspectiva da alimentação. Feito isso, iniciou-se a pesquisa qualitativa e um estudo de caso

* Bacharel em turismo pela Universidade Federal do Pará (UFPA). Especialista em Planejamento e Gestão Pública do Turismo e do Lazer pelo Núcleo de Altos Estudos Amazônicos (NAEA/UFPA). E-mail: mareco.cassia@gmail.com

* Ph. D. em Antropologia e Pós-Doutorado pela Universidade da Cidade de Nova Iorque (CUNY). Professora/pesquisadora do Núcleo de Altos Estudos Amazônicos (NAEA) da Universidade Federal do Pará (UFPA). E-mail: simonianl@gmail.com 
sobre o uso da imagem nas divulgações turísticas gastronômicas na cidade de Belém. Fez-se isto com questionários aplicados a turistas.

Com este artigo, buscou-se contribuir para o modo como se desenvolve a relação turismo e imagem enquanto permeada pela gastronomia; neste último aspecto, particularmente quanto à gastronomia paraense. A exemplo de Simonian (2007) e de Lisboa e Simonian (2011), a discussão ora efetivada revela outras questões que precisam ser aprofundadas.

\section{Turismo - Aspectos teóricos}

O turismo é um dos segmentos que ascendeu com a globalização a partir de 1970 (Lisboa e Simonian, 2011). Isso resultou da busca crescente pelo "novo" e "diferente", que surgiram com o desenvolvimento da sociedade contemporânea. Por englobar conjuntos de empresas privadas e instituições governamentais, a atividade passou a se destacar economicamente, tornando-se alvo de estudos por ciências diversas, como a economia, a antropologia, a sociologia e a geografia.

Pelo fato de economistas, geógrafos, administradores, entre outros, analisarem o turismo, existem definições diversas acerca do fenômeno.

"A proposta de Beni é que o turismo seja visto como um sistema composto de três conjuntos: Conjunto das relações ambientais (com os subsistemas ecológico, social, econômico e cultural); Conjunto da organização estrutural (com os subsistemas superestrutura e infraestrutura) e conjunto das ações operacionais (com os subsistemas mercado, oferta, demanda, produção, distribuição e consumo)" (Beni apud Panosso Netto, 2005: 66).

Dessa maneira, o turismo é visto pelo autor de modo sistêmico. Também, Christofoletti (1979, apud Panosso Netto, 2005) analisa o turismo a partir de sistemas, o qual se fundamenta nessa teoria aplicada à geografia.

Mas como uma atividade econômica e social, o turismo evolui de acordo com as mudanças da sociedade. Ademais, o perfil do turista não é diferente, pois nota-se que muitos viajantes procuram algo mais personalizado e diferenciado. Fagliari (2005) afirma que tais anseios se dão por fatores distintos e dentre eles estão a influência dos meios de comunicação e o aumento da expectativa de vida.

Entretanto, as preocupações com o fluxo mercadológico da atividade esconderam o que está por trás do deslocamento das pessoas (Panosso Netto, 2005). Nessa perspectiva, coloca-se o ser humano como responsável único pela configuração do que se chama fenômeno turístico. Segundo Panosso Netto:

"A infraestrutura, a região de destino, os demais aspectos do turismo só são abordados pelo turismo porque o ser humano decidiu viajar. Assim, consideramos que esses aspectos são fundamentais da prática do turismo - os fundamentos do fato turístico. Esses fundamentos, por serem matérias sem vida, não possuem valor em si mesmos. É necessário que o ser humano estabeleça o seu valor pelo uso" (Panosso Netto, 2005: 31).

Portanto, o ser humano se apresenta como único autor do turismo, isso porque busca conhecer e desfrutar de outras realidades. Assim, surgem os facilitadores, representados pelas empresas turísticas.

Além desses aspectos, destacam-se, ainda, outras questões que o turismo pode engendrar. Dentre elas, em sua análise sobre turismo e globalização, Cohen (2012) chama a atenção à propagação de etos modernos e consumistas que surgiram a partir da indústria do turismo, inclusive em lugares remotos e não ocidentais. Ainda segundo Cohen (2012), para muitos pesquisadores, o turismo é visto, como uma indústria crescente feita para o gozo de experiências, ao invés da geração de benefícios.

Mendonza-Ontiveros e Monterrubio (2014) identificaram, por meio de pesquisas, que residentes de comunidades passaram a copiar comportamentos de turistas, como por exemplo, o consumo de bens antes desconhecidos. Para eles, em certos casos, o turismo é capaz de influenciar a estrutura interna de locais em relação às crenças e valores. Tais efeitos são reportados, frequentemente, como consequências prejudiciais do turismo às populações locais.

\section{Fotografia e suas implicações no turismo}

A imagem fotográfica buscou estabelecer, segundo Jacques (1993), ao longo de sua história e das produções humanas, uma relação com o mundo; isto é, as imagens passaram a conversar com os acontecimentos e ideias dos indivíduos. Com os avanços tecnológicos e de técnicas fotográficas, a fotografia foi inserida em segmentos diversos, como o turismo (Hadlich, 2008), por meio do registro de elementos culturais das localidades e como recurso publicitário (Dropa et al., 2011). Dessa maneira, o uso de imagens fotográficas se mostra fundamental à atividade turística. 
Capaz de converter informações em registros visíveis, a fotografia é utilizada, também, como um instrumento da ciência (Spencer, 1980 apud Santos Junior, 2007). Desse modo, contribuiu para a realização de pesquisas teóricas. Quanto a isso, destaca-se Simonian (2007), que analisou o uso da fotografia em produções científicas na Amazônia.

Neves (2008, apud Coelho Neto e Urias, 2011) define a imagem como uma representação fiel ou não do objeto, que tende a ser percebida pelo indivíduo uma realidade concreta. Com relação ao indivíduo, Jacques (1993) propõe que aspectos como afetos, crenças, contextos históricos, entre outros, influenciam na percepção e interpretação de uma imagem. Assim, a imagem é criada por conteúdos escolhidos e por interpretações do espectador (Gombrich, 1965 apud Jacques, 1993), visto que o mesmo participa dessa construção.

No turismo, o espectador seria o turista que, segundo Hadlich (2008), lê a imagem a partir de um conjunto de informações e concepções prévias. Já Gombrich (1965, apud Jacques, 1993) abordou a imagem a partir de sua influência sobre o espectador. Dentre essas abordagens, é de enfatizar-se a "Influência da imagem" no que concerne à emoção que pode ser desencadeada no indivíduo por meio de uma regressão momentânea, produzida com um objetivo a esse espectador. Tal abordagem é denominada de Imagem espetacular.

No turismo, segundo Hadlich (2008), a fotografia está inserida em um processo que visa a construção de desejos a serem consumidos por pessoas por meio de informações sobre diversidades étnicas e seus elementos culturais. Do mesmo modo, a curiosidade se constitui em elemento fundamental para a motivação do turista, ao qual são apresentadas atrações estranhas à sua rotina, a exemplo de cachoeiras e comidas exóticas.

É preciso entender a fotografia não apenas como instrumento de ilustração e contemplação, mas como modo de evidenciar e documentar um fragmento da realidade exposta (Simonian, 2007). Por isso e desde tempos, muitos pesquisadores estimularam o uso da fotografia, como Emílio Augusto Goeldi (Simonian, 2007), na região amazônica. A partir dessa autora, define-se a fotografia como uma possibilidade para a comprovação de resultados de pesquisas feitas em campo. Aliás, associada a essa questão, Simonian (2011) expôs um trabalho de pesquisa fotográfica sobre cozinhas caboclas amazônicas, que dá bem a dimensão dos loci interioranos de produção de alimentos.

Recentemente, houve uma revolução tecnológica e a popularização do uso de câmeras, notadamente, das digitais. Tal perspectiva mudou tanto a produção científica como o cotidiano das pessoas e, ainda, o fazer turístico. Precisamente, quanto aos turistas, estes não apenas se inspiram em imagens para definir viagens e roteiros, mas as produzem, em sua quase totalidade, em fotografias, que geralmente veiculam nas mídias sociais.

Desse modo, surge a indagação quanto aos elementos presentes em imagens que são divulgadas na promoção da gastronomia paraense. Será que as mesmas estimulam, no observador, a curiosidade e o desejo colocados por Hadlich (2008)? Entende-se que a fotografia é um instrumento fundamental para o turismo, a partir de sua inserção em folhetos, cartões postais, revistas, HP etc. Também, a mesma resulta em registro, documento ou em lembranças de quem visita um local e consigo leva as fotografias de lugares que considerara interessantes.

\section{Aspectos histórico-culturais da gastronomia brasileira}

Com a chegada dos portugueses e etnias africanas, por meio do trabalho escravo e de encontros com a cultura indígena, o Brasil transformou-se em país multicultural (Lisboa e Simonian: 2011). Tal característica se expressou bastante nas cozinhas (Fagliari, 2005), em função da tendência de reprodução dos pratos da elite europeia. Porém, com a indisponibilidade de alguns ingredientes, houve a necessidade de se substituir ou acrescentar por outros regionais.

O resultado deste encontro de paladares e sabores está presente nas cozinhas das regiões brasileiras (Ribeiro, 2012): tem-se o alho (Allium sativum L.), trazido da Europa e da África; o dendê (Elaeis guianeesis), proveniente da África; e do indígena amazônico, o Jambu (Spilanthes oleracea L.). Este último é muito usado em receitas da região norte do país. Devido às extensões entre tais regiões, os produtos alimentícios para a subsistência e para a comercialização se deram de maneiras diferentes (Silva: 2005); também, houve influências climáticas e culturais dos povos que nelas se estabeleceram.

A região nordeste possui receitas variadas com milho (Zea mays), como a pamonha, devido à facilidade de plantação do produto na região (Fagliari, 2005). Há ainda o uso frequente do dendê, por influência africana. Na região sudeste, têm-se os pratos mineiros com bastante expressão cultural, como o feijão tropeiro, ${ }^{1}$ criado pelos tropeiros ou condutores de tropas. Além da mineira, há ainda a culinária paulista, capixaba e fluminense na mesma região.

Na região centro-oeste, Fagliari (2005) lembra que houve imigração devido à construção da capital do país, em 1956. Por isso, apresenta aspectos diversos da cultura indígena e de outras regiões brasileiras, 
como a nordestina. Devido à localização, a população dos Estados do Mato Grosso e Mato Grosso do Sul consomem peixe de água doce. Já a região sul apresenta predominância de descendentes de alemães, italianos, poloneses e de outros europeus, o que justifica a influência europeia na culinária.

Finalmente, tem-se a região norte, cuja influência indígena se caracteriza pelo consumo de peixes amazônicos, pelas frutas silvestres e pelas receitas à base de mandioca (Manihot esculenta Mart.) (Fagliari: 2005). Uma peculiaridade da alimentação desta região é a herança de costumes indígenas e, entre eles, o hábito de preparar e consumir alimentos ao ar livre, o que ainda é muito frequente. Para Lisboa e Simonian (2011), o auge da produção da borracha do Pará promoveu uma migração de nordestinos, proporcionando a contribuição destes à culinária local.

Devido às particularidades alimentícias, permitiu-se ao colonizador um estilo de vida novo e um paladar renovado, o que, parcialmente, se deve à dependência da mão de obra indígena e negra e ao contato com as florestas e águas amazônicas, precisamente aos seus recursos alimentícios. Conforme Silva (2005: 22), a região "[...] se encarregou de espalhar o tempero pelo cotidiano alimentar do Brasil colonial [...]". Ao tratar-se de autenticidade, especificamente da culinária paraense, Lisboa e Simonian (2011: 15) afirmam que "[...] esta culinária teria que usufruir da condição de integração ou ordenação privilegiada dentro da culinária brasileira [...]”.

A gastronomia tem tido papel importante na criação de roteiros turísticos, pois empresas já fazem passeios a certos locais a fim de conhecer a culinária da região (Crotts e Jaksa, 2006). Wolf (2002, apud Crotts e Jaksa, 2006) define turismo gastronômico como uma viagem a fim de procurar e desfrutar de comida e bebida preparadas, que produzem e trarão lembranças de experiências gastronômicas. Para Crotts e Jaksa (2006), a gastronomia é um corpo de conhecimento com suas raízes em todas as civilizações clássicas; no entanto, nos contextos de hospitalidade e turismo, a gastronomia é uma área de estudo nova.

\section{A Amazônia sob a perspectiva da alimentação}

$\mathrm{Na}$ Amazônia, a alimentação paraense tem um significado importante desde os tempos pré-coloniais. Elementos arqueológicos são evidências disso, como panelas, fornos, alguidares, potes e raladores de cerâmica, o que se verifica em Acunã (1941) e em Ferreira (1974). Silva (2005: 10) afirma que:

"A comida tem uma função básica, ligada diretamente à cultura material, que diz respeito, em primeiro lugar, à subsistência. Nesse sentido, há uma lógica da comida que opera no plano concreto e que dialoga com o contexto, evidenciando uma relação própria entre culinária e cultura".

Acunã (1941) trouxe à tona uma variedade de produtos alimentares e de comidas utilizadas pelos indígenas amazônicos do século XVII. Desde então, muitos são os registros a respeito dos recursos da floresta e rios usados pelos indígenas. Com relação a esses meios, têm-se frutos, raízes, caules, folhas, sementes, animais aquáticos, terrestres e aéreos. O mesmo se pode dizer quanto aos modos de preparo dos alimentos e às situações em que as comidas são consumidas e comercializadas.

A cozinha amazônica tem uma composição bastante orgânica e apresenta uma singularidade em sua estrutura étnica. Deste modo, é considerada por muitos autores como a mais típica do país. Além disso, Orico (1972) ainda supôs que por estar associada à terra e às águas da região, torna-se difícil a sua expansão e aceitação, uma vez que necessita de seu habitat.

Tem-se, também, o mangal, de onde são consumidos alimentos como o caranguejo (Trichodactylus spp) e o turu (Teredo sp). A considerar-se a posição de Maués e Maués (1980), também há a várzea, onde cresce o açaizeiro (Euterpe oleracea Mart), do qual se extrai a polpa denominada açaí. E, finalmente, a terra firme, onde se localizam plantações de mandioca e de árvores frutíferas, além dos animais domésticos e caças.

A cozinha da Amazônia é marcada pela autenticidade, especialmente a paraense, por seus elementos e condimentos autóctones. Ao analisarem a gastronomia amazônica, Lisboa e Simonian (2011) assim se posicionam e entendem que está relacionada à história, às relações sociais e às escolhas de uma comunidade. Por isso, ela mereceria uma 'integração ou ordenação privilegiada', na culinária brasileira, por sua origem estar extremamente ligada aos indígenas. Alguns estabelecimentos, como restaurantes e hotéis de Belém, já aproveitavam elementos regionais para atrair clientes, o que já foi observado:

"Continua viva em nós a Amazônia de nosso tempo de criança: o açaí de depois-do-almoço, a chuva das duas da tarde, o tacacá das quatro, os sorvetes de cupuaçu e taperebá da terrasse do antigo Grande Hotel e, ainda, os casquinhos, os pastéis e unhas de caranguejo das barracas de palha da festa de Nossa Senhora de Nazaré" (Orico, 1972: 6). 
Mesmo com uma tecnologia simples, os povos indígenas criaram seus "cardápios" conforme o que encontravam ao alcance de seus arpões, flechas e armadilhas de caça.

Nos termos desse autor, os índios construíram hábitos alimentares, muitas vezes repelidos em outras regiões. Tem-se um exemplo na França, onde a “[...] piraiba (Brachyplathystoma filamentosum), grande parte dos peixes de pele, aves e pássaros em certas épocas do ano, que constituem para nós motivos de satisfação para o paladar, eles repeliam por nocivos à saúde [...]" (Orico, 1974 apud Orico, 1972: 25). Vê-se, assim, uma diversidade gastronômica.

Segundo Orico, a cozinha amazônica, inclusive a paraense, inicia nos portos. Em relação ao Ver-o-Peso, o autor fez a seguinte abordagem:

"É o elemento vivo de troca e de barganha, o embarcadouro onde, manhã cedo, vai abastecer meia população.

É lá que se encontram inicialmente os elementos e condimentos que irão fumegar na panela das casas, obedecendo às receitas e ditamos de uma culinária em perfeita correspondência com os produtos da região" (Orico, 1972: 31).

O autor acredita que a "felicidade do estômago" começa desde o momento em que o feirante vê na praia, no trapiche ou no mercado, as pimentas (Caspicum L.), as postas de peixe e o paneiro de farinha que irão compor a sua mesa.

O peixe é o alimento que representa a fonte maior de proteína da Amazônia (Murrieta, 2001). Compreende-se que seu consumo é determinado por fatores diversos. Entre eles, estão as variações sazonais ecológicas, as habilidades do pescador e a sorte no momento da pesca. Nas últimas décadas, o consumo de carne de gado aumentou significativamente.

Além disso, podem-se incluir, ainda, fatores como comportamento, dieta, cor, cheiro e aparência, nos processos de classificação e escolha. Para Murrieta (2001), na ilha de Ituqui, localizada na parte baixa do Amazonas, Pará, os moradores costumam classificar os peixes em "fortes", devido à estrutura fibrosa da carne, e em "fracos", por serem facilmente digeríveis.

Conforme essa pesquisa, a tradição classifica como reimosos os alimentos prejudiciais ou não adequados. Já os não reimosos são aqueles não prejudiciais à saúde, principalmente aos enfermos, às mulheres menstruadas e às que se encontram no pós-parto. Entre os alimentos que merecem cuidados no consumo, identificados por Murrieta (2001), estão os peixes "lisos" ou "de pele".

Maués e Maués (1980) analisaram a existência de tabus na alimentação amazônica, na qual alguns alimentos não são considerados "bons de comer". Entre eles se encontram os insetos, alguns peixes, como o baiacu (Diodon holocanthus), e vegetais, como a aninga (Montrichardia linifera). Esses mesmos autores concluíram que tais definições acerca do que é comestível ou não são determinações culturais, que se perpetuam por meio das gerações, e não postas pela natureza.

As complexas regras relativas à reima estão relacionadas com uma série de fatores que envolvem, além do alimento, os rituais como o xamanismo e a visão de mundo que os habitantes possuem. Em Itapuá, não se usa a palavra reima, apenas os termos "reimoso", para alimentos que fazem mal, e "manso", para os que são inofensivos. Vale ressaltar, também, a questão dos alimentos reimosos ou não, pois tais definições são presentes no cotidiano da população amazônica.

Ainda, ressalta-se que a cultura das festas tradicionais tinha como um dos atrativos os alimentos típicos. Como exemplo, tem-se as festas de Arraial, tradicionais em eventos religiosos e enraizadas nas crenças de pajés (Orico, 1972). Dentre estas, o autor destaca a festa do mestre Martinho, no bairro do Umarizal, na capital Belém, onde não podiam faltar os quitutes regionais.

Orico (1972: 59) também abordou a importância das quituteiras doceiras. Assim, afirmou que elas são "[...] elementos indispensáveis na composição da cozinha amazônica". Segundo o autor, elas são profissionais que conhecem todas as técnicas de seus pratos, desde a matança de um pato (Cairina moschata) até ao refogado no tucupi.

Até aos dias atuais, são notáveis as "tacacazeiras" (vendedoras de tacacá), as quais desempenham papel importante na promoção desse alimento. Elas acabaram se tornando atrativos turísticos, uma vez que são procuradas por turistas que desejam provar o tacacá. Além disso, sabe-se que os habitantes não dispensam o tacacá das cinco da tarde.

A pintora paraense Antonieta Santos Feio retratou em sua obra "Vendedora de tacacá" uma "tacacazeira", a qual pode ser observada na Figura 1. A obra consiste em uma pintura a óleo. Sua expressividade é enorme para os contextos gastronômicos e artísticos regionais. 
Figura 1: A vendedora de tacacá

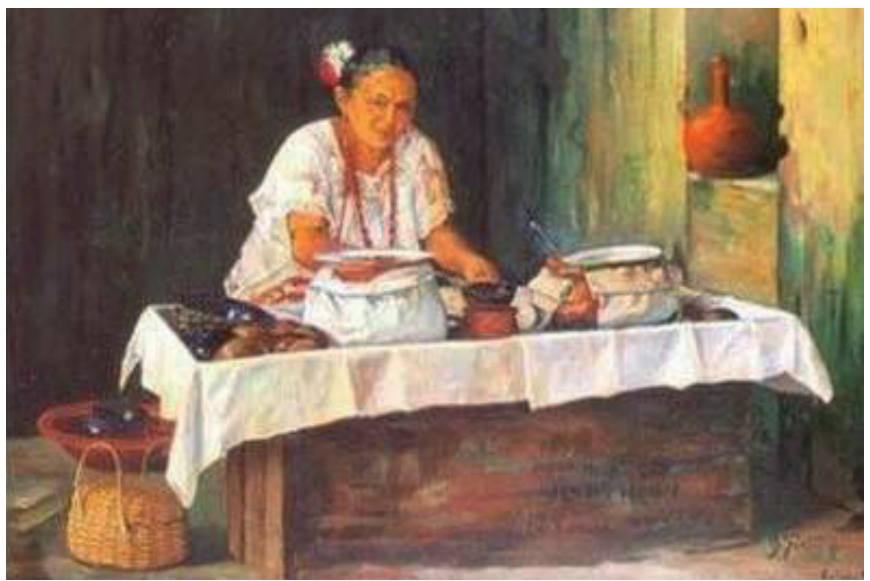

Fonte: Tela de Antonieta Santos Feio, 1937, 12/05/2013.

Uma das bases indispensáveis para os pratos da culinária amazônica é a mandioca. Pereira (apud Orico, 1972: 79), que esteve entre os índios Maués, afirma que "[...] a raiz comestível da mandioca teria nascido do corpo de Mani, morta de amores infelizes, e que na terra renasceu como raiz [...]". Já na culinária amazônica, a afirmação da farinha se deu de modo bastante peculiar, uma vez que a mesma foi associada, inicialmente, às classes consideradas "inferiores".

Esse fato predominou por influência das elites dominantes, demonstrando o menosprezo que havia com relação à população indígena. Para Murrieta (2001), o chibé - espécie de mingau ou bebida - é um exemplo desta associação, mediante a expressão "papa-chibé". Tal expressão refere-se às pessoas com poderes aquisitivos menores, muito embora esse quadro tenha sofrido alterações, estando atualmente nos restaurantes mais caros e nos mais acessíveis. Ver Figuras 2 e 3, em que a farinha aparece sendo vendida no mercado Ver-o-Peso e em potes sobre a mesa de um restaurante.

Figura 2: Comercialização de farinha

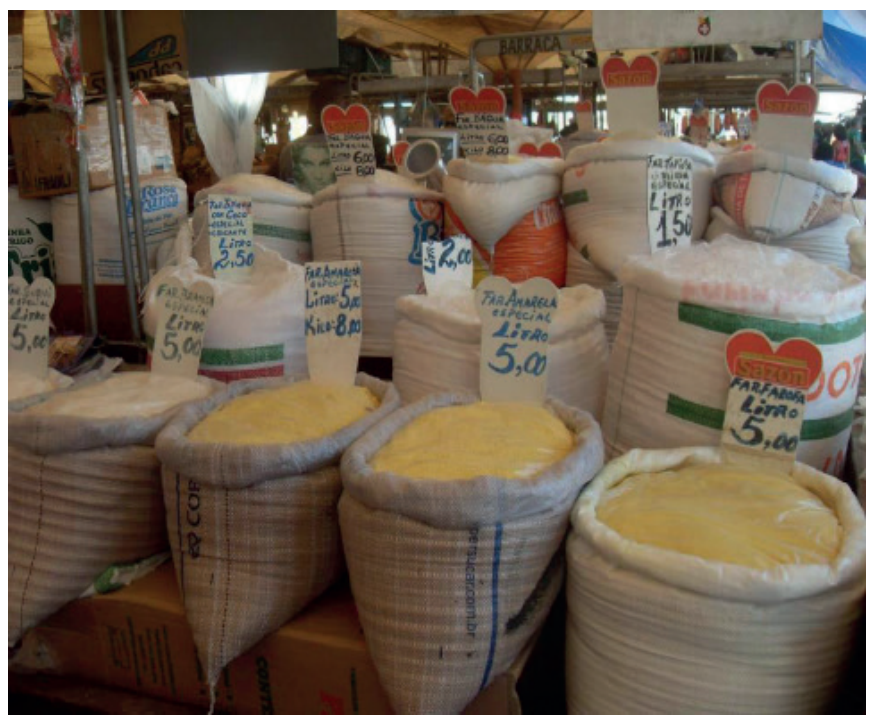

Fonte: Fotografia de C. A. Mareco, 20/06/2013. 
Figura 3: Usos da farinha na culinária

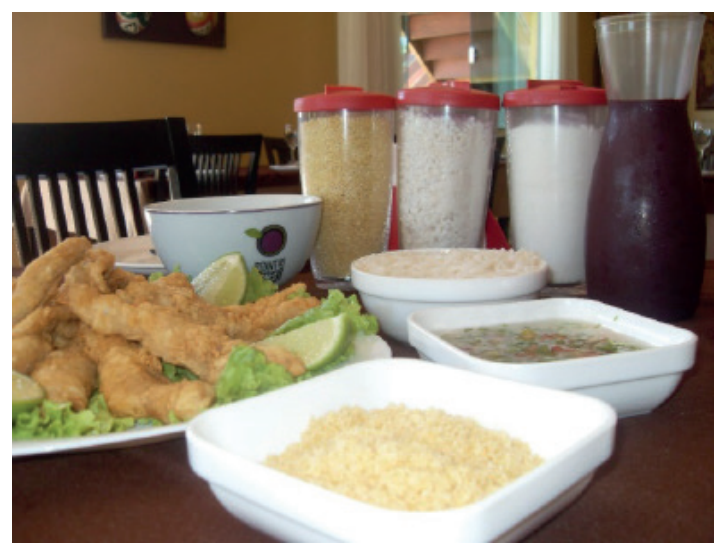

Fonte: Fotografia de C.A. Mareco, 17/07/2013.

Ainda, Murrieta (2001) constatou que a farinha de mandioca é a fonte mais confiável de energia de origem não animal para as populações rurais da Amazônia. No caso de Ituqui, sinaliza-se que a farinha e seus derivados somam $25,2 \%$ e $34,0 \%$ do total consumido de energia.

Em certo período da história, a produção do tucupi era função exclusiva das mulheres que não estavam menstruadas. Porém, o ritual foi modificado com o decorrer do tempo, uma vez que ninguém pôde comprovar a relação existente entre a preparação da mandioca e os impedimentos da natureza. A partir da mandioca, é retirado o sumo, que é a base desse produto.

Esses são um dos pratos tradicionais da Amazônia: o tacacá e o pato no tucupi. Segundo Mata (apud Orico, 1972), o tucupi é o sumo gerado a partir da mandioca descascada e ralada; ao ficar em repouso, o sumo deixa um sedimento esbranquiçado, que depois de seco dará origem à tapioca.

Mas não se pode falar da culinária amazônica sem, ao menos, citar algumas bebidas. Além do chibé, tem-se a cayssuma, que é preparada com milho, mandioca e batata doce. Esta pode causar embriaguez, dependendo do tempo de fermentação.

A Amazônia é conhecida por sua variedade de pimentas, sendo que as mesmas não podem faltar na mesa da maioria da população (Orico, 1972). Dentre elas, a pimenta de cheiro (C. chinense) e a pimenta-rosa (Schinus terebinthifolius). A presença de pimentas pode ser observada nas Figuras 4 e 5, em que aparecem sendo vendidas no mercado Ver-o-Peso. Já a Figura 6 mostra uma feirante preparando a pimenta, nesse mesmo mercado, para torná-la molho de pimenta com tucupi.

\section{Figura 4: Comercialização de pimentas I}

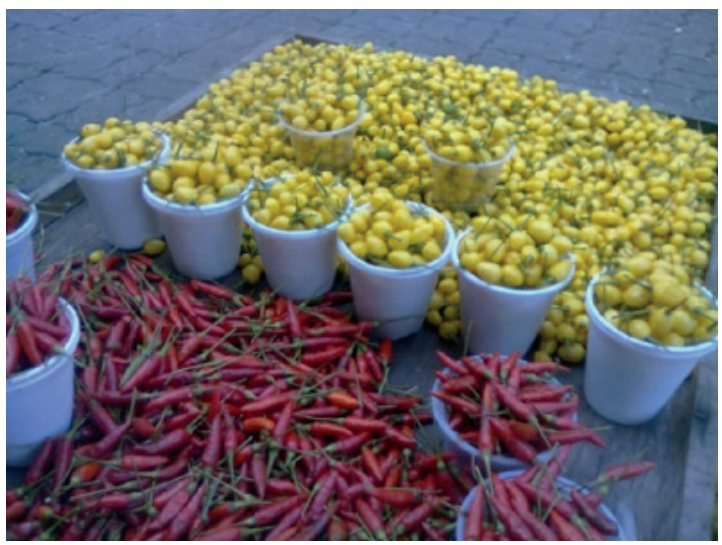

Fonte: Fotografia retirada do celular do vendedor, 20/06/2013. 
Figura 5: Comercialização de pimentas II

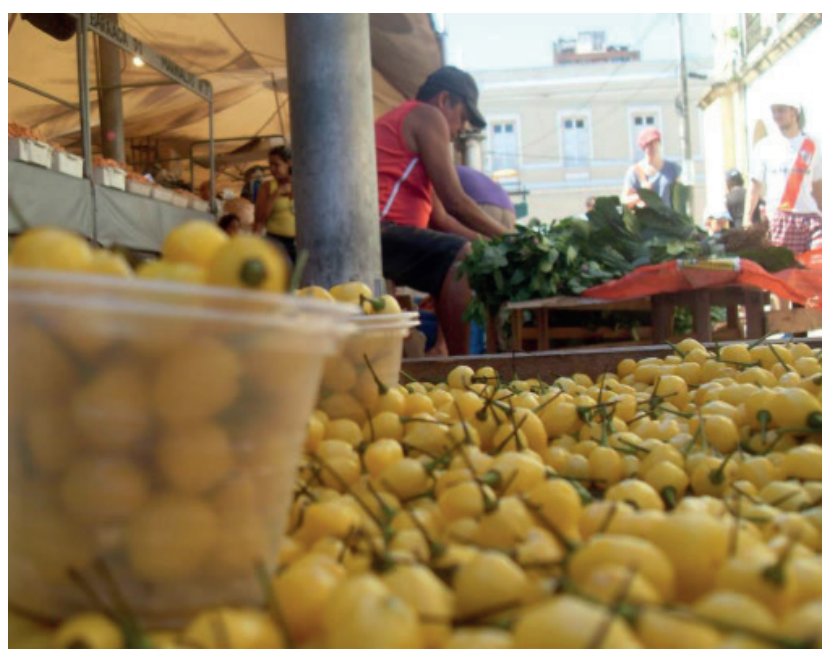

Fonte: Fotografia de C. A. Mareco, 20/06/2013.

Figura 6: Tucupi com pimenta

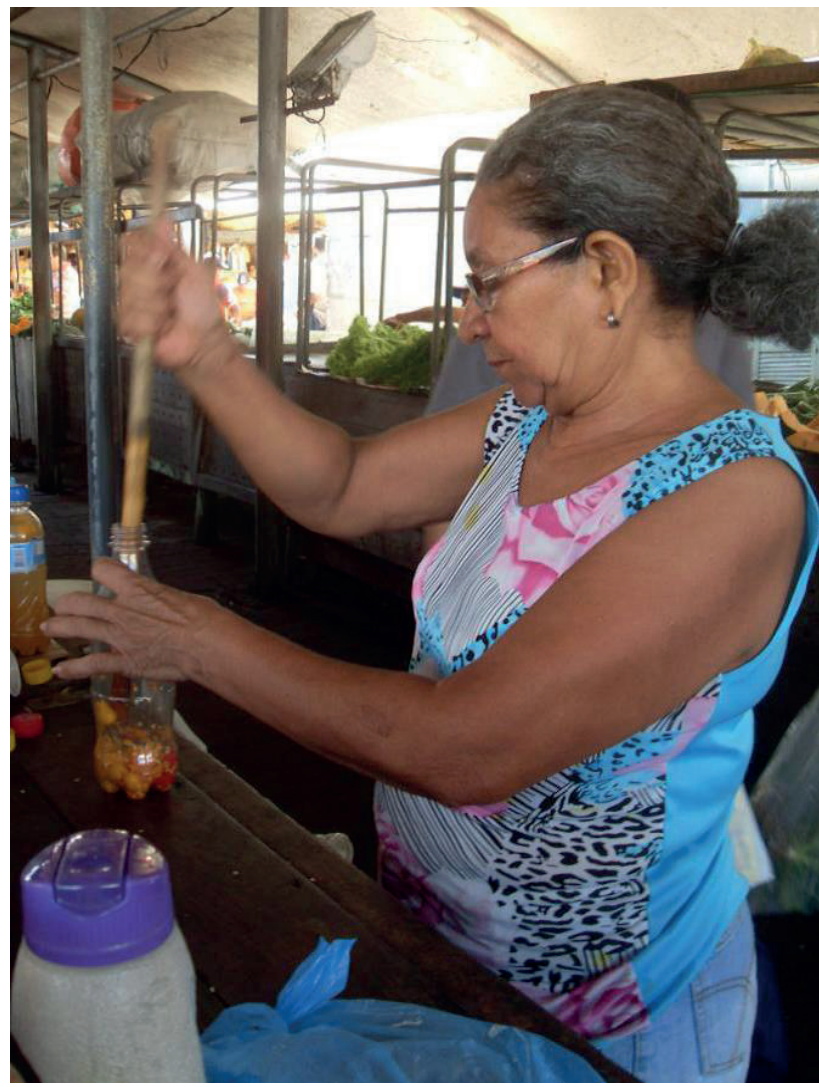

Fonte: Fotografia de C. A. Mareco, 20/06/2013. 
No que diz respeito às frutas da Amazônia, essas estão entre as mais incomuns do país, por serem encontradas somente nesta região. Entre elas, podem-se citar o cupuaçu (Theobroma grandiflorum), uxi (Endopleuea uchi (Huber) Cuatrec), taperebá e bacuri (Platoniain signis Mart.). Esse último foi adotado, segundo Orico (1972), pelo Barão de Rio Branco como sobremesa nos banquetes do Itamarati, pois o mesmo era um apreciador da fruta.

Destaque especial se dá ao açaí, a bebida mais conhecida pela população amazônica. A referida bebida é preparada a partir dos frutos do açaizeiro. Antigamente, esses caroços eram mergulhados em um alguidar, no qual eram amassados pelas mãos da amassadeira. Isso normalmente era tarefa de mulheres, que amassavam os carocinhos e adicionavam água fresca para, uniformemente, macerá-los (Orico, 1972). Porém, atualmente utilizam-se máquinas para facilitar e acelerar a produção do vinho do açaí, participando tanto homens como mulheres. Na Figura 7, observa-se o açaí comum (do lado esquerdo) e o açaí branco (do lado direito) sobre o balcão no mercado Ver-o-Peso.

\section{Figura 7. Polpa de açaí}

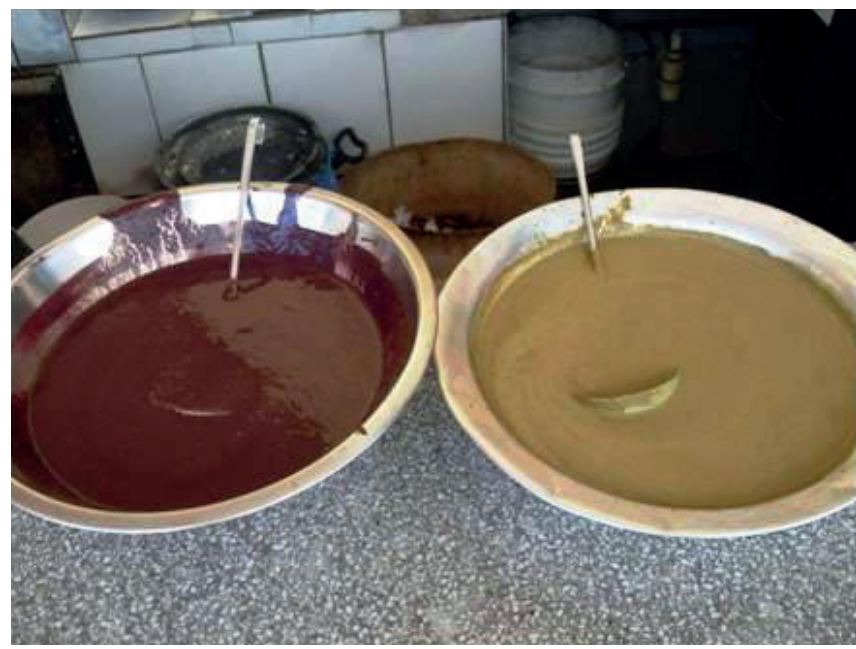

Fonte: Fotografia de C. A. Mareco, 20/06/2013.

Orico (1972) identificou que a culinária de Manaus (capital do Amazonas) sofreu influências diversas com a implantação da Zona Franca. Este acontecimento se deu devido à chegada de produtos estrangeiros; e, dentre esses, os enlatados e os gelados americanos e, mais recentemente, os produtos orientais.

Salienta-se que o amazonense aprecia a carne de tartaruga (Podocnemis expansa) e um esparregado de caruru com ovos. Além disso, se deleita com quiabo no caruru ou com ovos, do mesmo modo que se delicia consumindo camarões com maxixe (Cucumis anguria L.) fervidos com pimentões (Capsicum annuum L), entre outros pratos.

Localizado na Amazônia brasileira, ${ }^{3}$ o Estado do Maranhão apresenta uma culinária bastante peculiar ao resto da região. Há pratos que são encontrados somente lá (Orico, 1972). Provavelmente, isso ocorre pelo contato restrito que o local estabeleceu com o restante dos Estados brasileiros.

De acordo com Orico, (1972), o arroz de cuxá constitui um dos pratos mais conhecido do Maranhão, feito com vinagreira (Hibiscus sabdariffa). Além disso, encontram-se vocábulos diferentes para se referir a certos alimentos. Por exemplo: juçara, para açaí, e jurará, para casquinhos de muçuã (Kinosternon scorpioides).

$\mathrm{O}$ arroz é um alimento alternativo que foi introduzido na alimentação da Amazônia. Assim, o mesmo passou a compor pratos típicos diversos, como com a maniçoba e o com pato no tucupi. Murrieta (2001: 61) observou que o consumo do arroz era visto, a princípio, como um estilo de vida superior; "[...] seria assim um mecanismo discreto para estabelecer algumas distinções de classe [...]".

Pode-se destacar, ainda, o papel do café com açúcar. Foram trazidos por estrangeiros e ambos se tornaram alimentos bastante consumidos na Amazônia. Murrieta (2001) observou que seu consumo se tornou um item de socialização, pois ao chegar uma visita prontamente é oferecido um "cafezinho com açúcar". 
Orico (1972) dispõe de algumas informações relevantes, para a cozinha amazônica, relacionadas à sua propagação pelo país. Em comparação ao Rio de Janeiro, segundo o autor citado, que adotou churrascarias gaúchas e as moquecas de peixe de origem baiana, os pratos e produtos amazônicos também foram incorporados por certos empreendimentos. Mais recentemente, e a partir do Rio de Janeiro, o açaí espalhou-se pelo mundo, quer como polpa, quer como outros derivados.

Como exemplo disso, menciona-se o Arataca, no qual se encontrava pupunha (Bactris gasipaes), piquiá (Caryocar brasiliense Cambess), cupuaçu, taperebá, entre outros. Na Sucolândia também eram oferecidas frutas amazônicas. A Casa Bonifácio foi aberta por um português e comercializava castanha (Bertholletia excelsa H.B.K), camarões secos, tapioca e bacuri.

Os fatos narrados por Orico (1972) mostram que os produtos amazônicos despertavam o interesse em pessoas para levá-los a outros lugares. Buscava-se torná-los conhecidos e valorizados. Na secção que segue ver-se-á a importância de se conhecer quais os meios atuais que estão sendo usados para a divulgação desses alimentos aos visitantes e aos que desejam visitar a região amazônica.

\section{Resultados: pesquisa qualitativa}

Na pesquisa qualitativa, tomam-se critérios desconsiderados na pesquisa quantitativa, e é neste aspecto que reside sua importância. Segundo Teixeira (2009), as perguntas a serem consideradas são: qual a percepção; qual o significado; quais os saberes; e quais as práticas. Desse modo, foram apresentadas algumas questões às empresas privadas e instituições públicas ligadas à gastronomia belenense.

Perguntou-se se são utilizadas imagens referentes à gastronomia paraense. Questionou-se sobre a importância que essas imagens representam para o incentivo turístico tal como sobre quais elementos estariam presentes nessas imagens. Ademais, também se interrogou quanto à procura pela gastronomia paraense por parte dos clientes ${ }^{4}$. Perguntou-se, também, se existem iniciativas voltadas ao turismo gastronômico por parte das instituições públicas.

A Valeverde Turismo foi a primeira empresa privada em que se efetuou a pesquisa. Segundo a entrevistada, a empresa faz uso de imagens da gastronomia paraense e atribui à culinária da região um referencial cultural significativo devido à variedade em animais, frutas, sementes, verduras e ervas. Também foi dito que o uso de tais imagens se justifica a partir da intenção de atrair a curiosidade dos turistas. No entanto, esses já têm o desejo de conhecer a cultura paraense. Ainda, a referida empresa entende que precisa vincular, por lidar com o turismo, a imagem à cultura da região.

Pelo fato de haverem sido usados em suas divulgações, os elementos principais citados são: tacacá, açaí e as ervas. Segundo a entrevistada, em relação à gastronomia paraense, há uma procura considerável por

Figura 8: Site Valeverde turismo

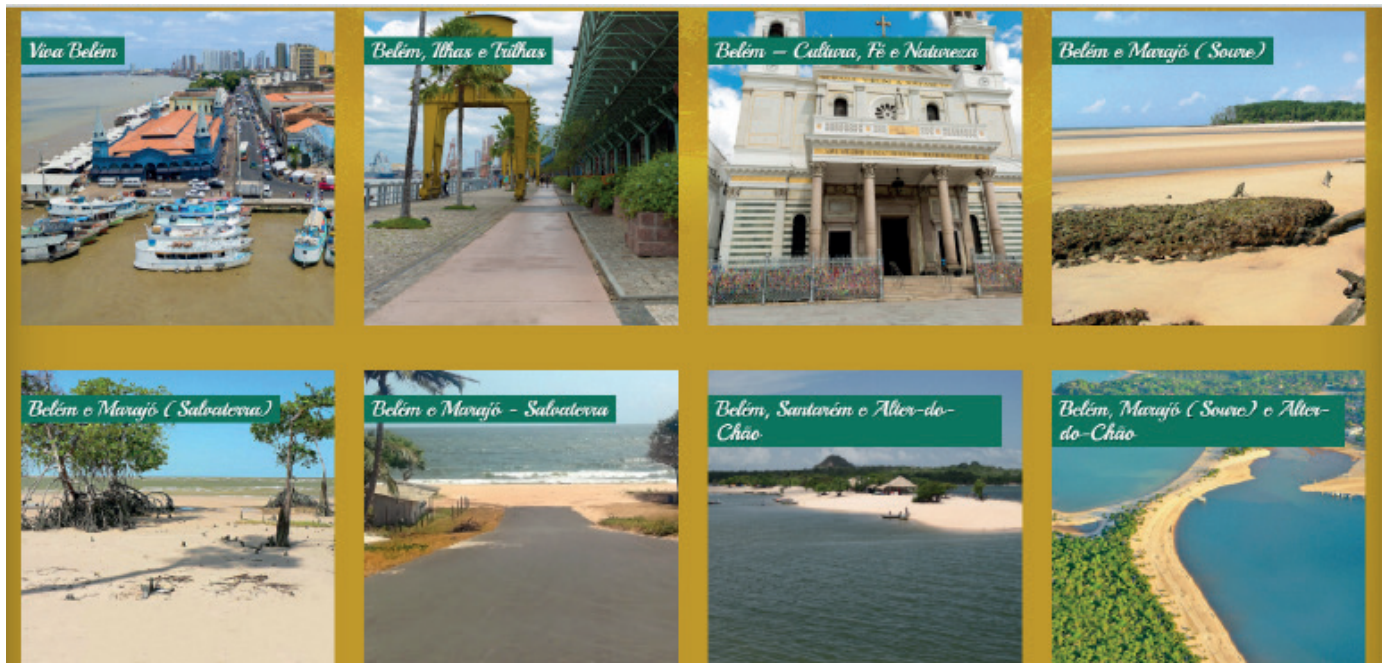

Fonte: www.valeverdeturismo.com.br, 05/07/2015. 
parte dos clientes. Por isso, nos passeios destinados aos turistas, feitos em embarcações próprias, há venda de comidas típicas para os participantes. Entretanto, percebeu-se a ausência de imagens relacionadas à gastronomia paraense no material de divulgação de pacotes turísticos receptivos. Chegou-se a tal consideração após a consulta do site da empresa e de materiais impressos, como folhetos, flyers, ${ }^{5}$ entre outros.

A empresa poderia fazer uso de imagens da gastronomia em suas divulgações, tendo em vista que a culinária dialoga com o contexto cultural, evidenciando uma relação própria com a cultura (Silva: 2005). A utilização de imagens possibilitaria a atração de visitantes que tivessem interesse por gastronomias, retirando a predominância de imagens de elementos verdes, como as praias e florestas (Figura 8). Além disso, a presença de alimentos da região como atrativo possivelmente despertaria interesse em muitos indivíduos que buscam o diferencial em suas praias.

A outra empresa (Travel Inn) também afirmou fazer uso de imagens da gastronomia paraense como um atrativo ao turismo receptivo. A justificativa se encontra no exotismo da culinária local por meio de combinações entre entradas, pratos principais e sobremesas. E os elementos fundamentais presentes nas divulgações são, segundo a entrevistada, as frutas, os peixes e todos os demais pratos regionais. Ela afirmou ainda que há uma procura considerável por parte dos turistas relacionada à gastronomia do Pará.

Com relação a essa empresa, o que mais chama a atenção é que no material impresso pesquisado não há imagens relacionadas à gastronomia paraense. Nota-se, no entanto, que o contrário ocorre no site da mesma (Figura 9). Ademais, a imagem mostrada do sorvete de açaí com tapioca apresenta pouca legibilidade.

Figura 9: Site TravelInn

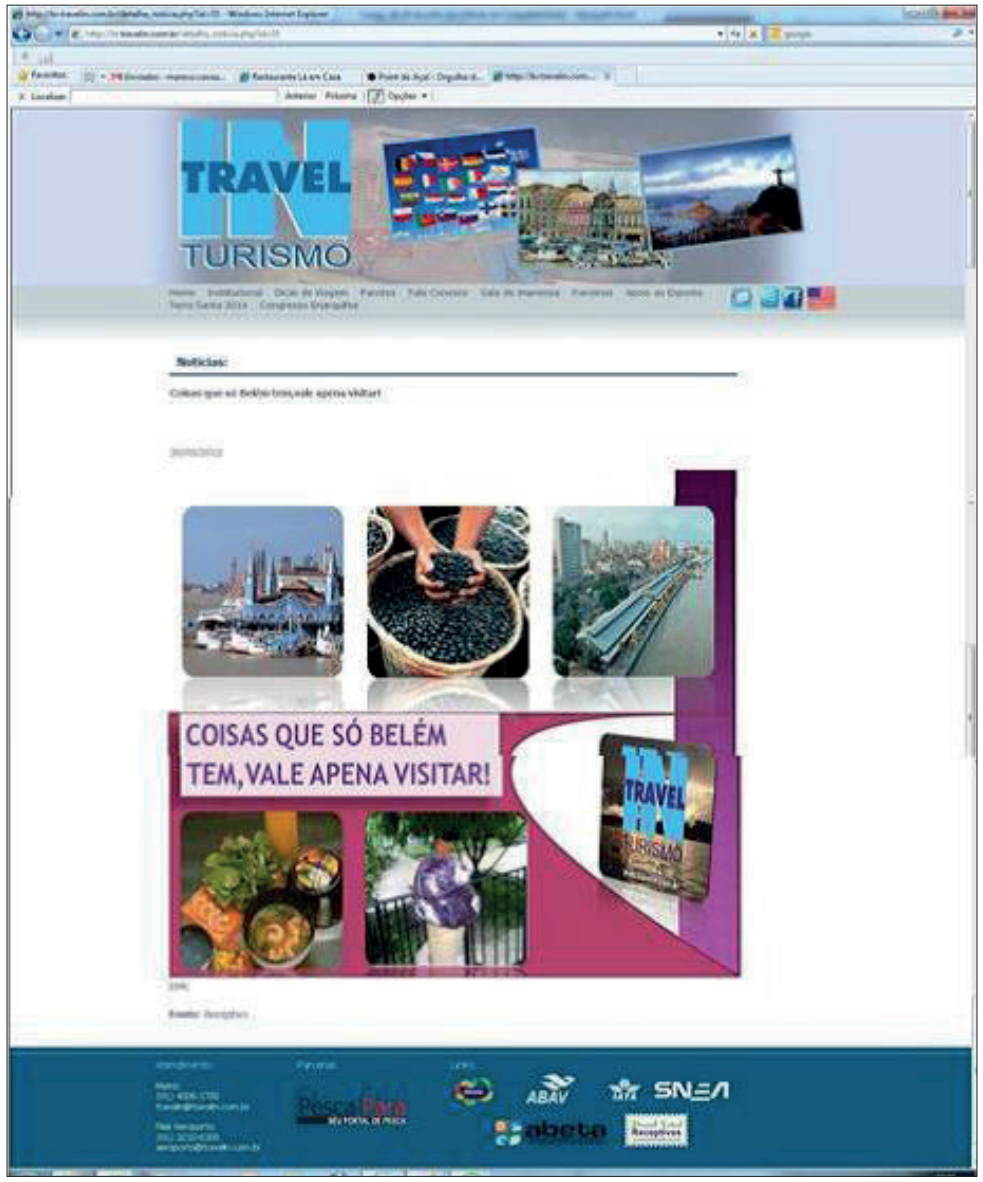

Fonte: Fotografia de C. A. Mareco, 05/07/2013. 
Isso permite inferir que, possivelmente, ela foi feita de cima para baixo, dificultando a visualização, principalmente com relação ao objeto vermelho (colher para tomar o sorvete), que se encontra no sorvete. Ao observar a figura, pode-se dizer que a imagem foi mal editada, deixando de apresentar o uso de cores que possam chamar a atenção, além de demonstrar ausência de boa iluminação. Mas, ao contrário do que foi visto, Hadlich (2008) revela que a fotografia está condicionada, no turismo, a instigar desejos e curiosidades.

A outra página do site mostra a mesa de um restaurante na ilha do Marajó (Figura 10). Nela podem ser vistos pães, cremes e alguns outros alimentos, como queijos e sucos. Tais imagens não possuem legendas sobre a composição da mesa. Também não é possível perceber qual o objetivo da imagem, o que dificilmente despertará a curiosidade e desejo de quem a acessar.

\section{Figura 10. Site TravelInn} Manhă livre. Ás 13 h traslado ao porto do Camará, para embarque com destino a Belêm. Chegada e transfer para
o hotel.

\section{INCLUSO NO PACOTE:}

Traslados - Hotel / Porto / Hotel, em Belém

Transporte em Barco Regional - Belém / Camará / Belém

Traslados - Porto Camará / Salvaterra / Soure / Porto Camar

Hospedagem com Café da manhã, no Hotel Casarão da Amazônia ou Hotel Illha do Marajó, de acordo com a

disponibilidade.

Guia de Turismo

Passeios descritos na programaçāo

Faça sua reserva para o pacote Boto 3 dias / 2 noites!

\section{FAC_A JA A SUA RESERVA}
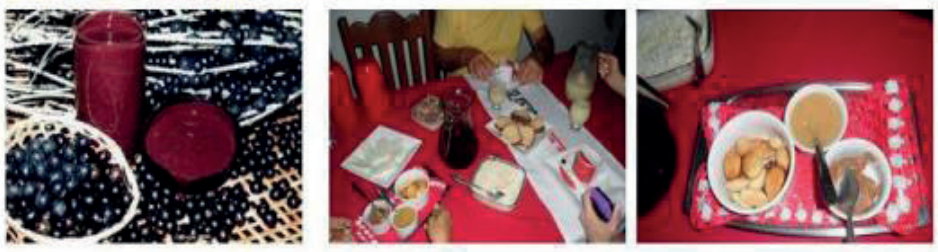

\section{SABOR MARAJOARA / PACOTE VIP}

Periodo (02 dias e 01 noite)

\section{DIA - BELÉM / SOURE}

Em horário pré-estabelecido, traslado do hotel ao porto, para embarque às 6 h $30 \mathrm{~min}$ com destino a Camarả, na Ilha do Marajó - o maior arquipélago fluviomarinho do Planeta, em uma viagem de aproximadamente 3 h. Chegada ao Porto de Camará. Traslado à cidade de Soure. Hospedagem. Em seguida, iremos conhecer a bela Praia do Pesqueiro e uma tipica Fazenda Marajoara. Retorno ao hotel no final da tarde.

\section{$2^{\circ}$ DIA - SOURE / BELÉM}

Após café da manhā, visitaremos Soure, enfatizando o centro da cidade, o Curtume (Centro de Processamento

Fonte: www.travelinn.com.br, 15/08/2015.

Foram questionadas, também, instituições públicas responsáveis pelo turismo no Estado do Pará e em Belém. A entrevistada da Coordenadoria Municipal de Turismo da Cidade de Belém (BELÉMTUR), afirmou usar imagens da gastronomia paraense. O argumento usado por ela foi o de que a mesma se apresenta rica e muito diversificada. Além disso, representa um dos mais importantes itens na divulgação do município e do Pará. Entre os elementos principais nas divulgações estão o açaí, a farinha de tapioca, o tacacá, o jambu e o tucupi.

Na página da folder turística da BELÉMTUR (Figura 11), reservada à gastronomia, são apresentadas cinco imagens de pratos regionais, bem decorados. O açaí aparece em destaque, pois sua imagem é exposta no tamanho $12 \mathrm{~cm}$ x 13,5 cm. Sua composição fotográfica exibe a farinha d'água e de tapioca, respectivamente, além dos grãos e das folhas da palmeira sobre uma esteira de palha. Ao tratar-se das outras imagens, encontram-se a maniçoba, o tacacá, o arroz paraense e o pato no tucupi. Todas essas fotografias são mostradas em tamanho médio, de $5 \mathrm{~cm}$ x $4,5 \mathrm{~cm}$. 
Figura 11: Gastronomia

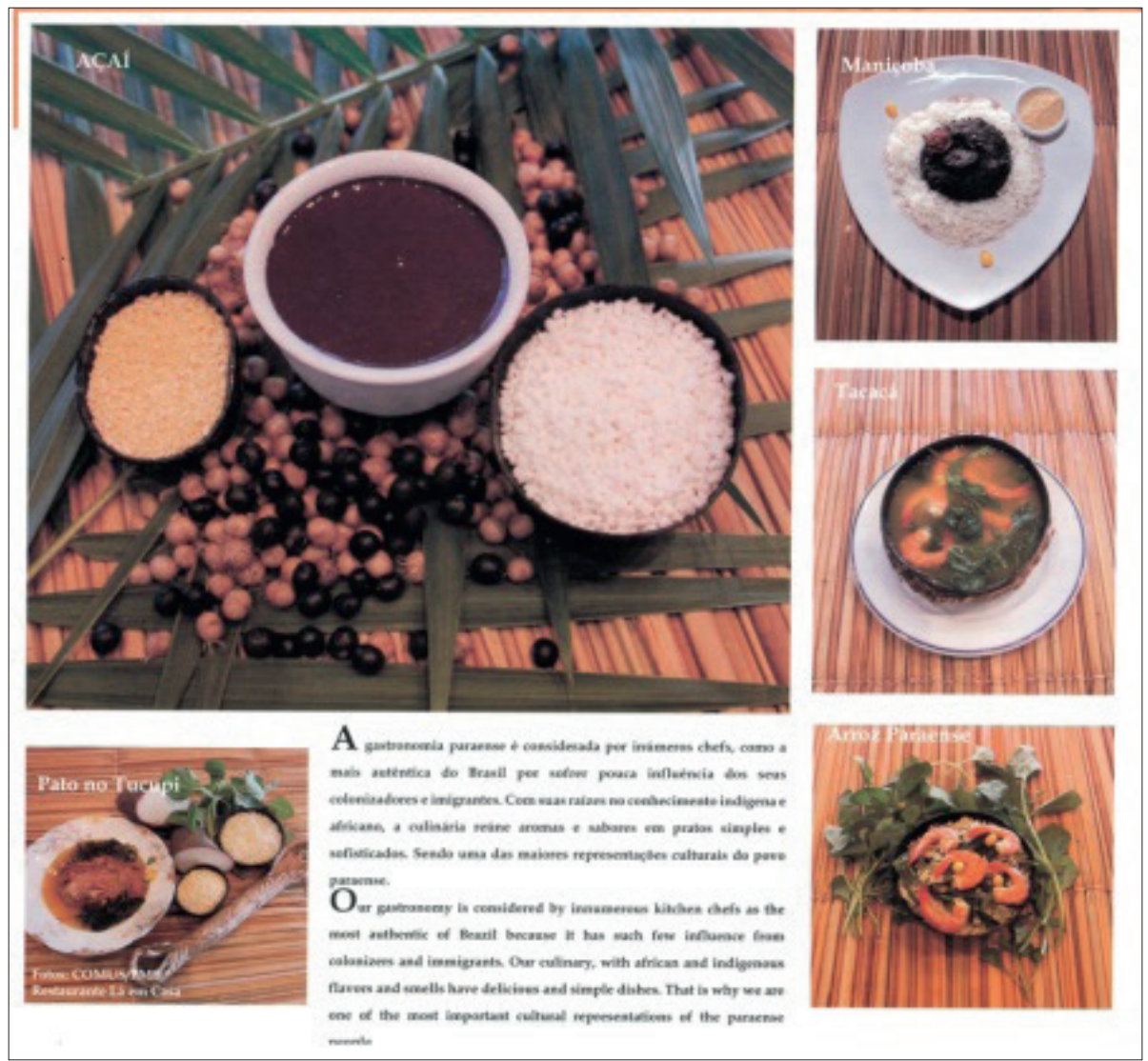

Fonte: Folder BELEMTUR, S/ data.

O editor do site se preocupou com a composição de cada prato, centralizando as iguarias na imagem. Para isso, explorou a luminosidade além de apresentar um utensílio característico na produção da farinha e do tucupi, o tipiti. Este é um espremedor feito em palha trançada, o qual é usado para escorrer e secar as raízes da mandioca. As imagens estão bem estruturadas, as cores bem exploradas e possuem legendas. Porém, o material é limitado, pois não é de fácil acesso, principalmente nos pontos turísticos.

Ao questionar a entrevistada sobre a procura considerável de produtos gastronômicos por turistas, a mesma asseverou positivamente. Então, perguntou-se-lhe se existe uma política ativa de promoção voltada ao turismo gastronômico. Porém, a referida informou que não existe, além de estar em elaboração um projeto novo de divulgação, o qual enfatizará essa categoria.

Com a função de promover os produtos da cultura paraense, a Companhia Paraense de Turismo (PARATUR) afirmou, por meio do responsável pelo setor de marketing, que existe o uso de imagem da gastronomia em suas promoções. Isso se dá pelo fato de a mesma estar inserida como um subsegmento da cultura. Para ele, o uso destas imagens é importante, pois a culinária paraense é mais que um atrativo, representa uma simbologia, principalmente a indígena, sem esquecer as influências africanas e europeias. Em suas divulgações, encontram-se os alimentos tradicionais, como o pato no tucupi, a maniçoba (Figura 12), a caldeirada, o filhote (Brachyplathystoma filamentosum) e o tacacá.

Na Figura 12, observa-se que o editor reservou uma lauda de $12 \mathrm{~cm}$ x $23 \mathrm{~cm}$ às duas imagens gastronômicas ( $21 \mathrm{~cm} \times 16 \mathrm{~cm}$ e $21 \mathrm{~cm} \times 13,5 \mathrm{~cm}$ respectivamente), na qual a maniçoba é apresentada em uma panela de barro, remetendo ao tradicionalismo. Na mesma página, evidenciou-se a diversidade de frutas regionais, ressaltando suas formas e cores. Na lauda posterior, têm-se comentários e receitas sobre alguns pratos típicos, como o arroz de pato e o tacacá. 
Figura 12: Maniçoba e frutas
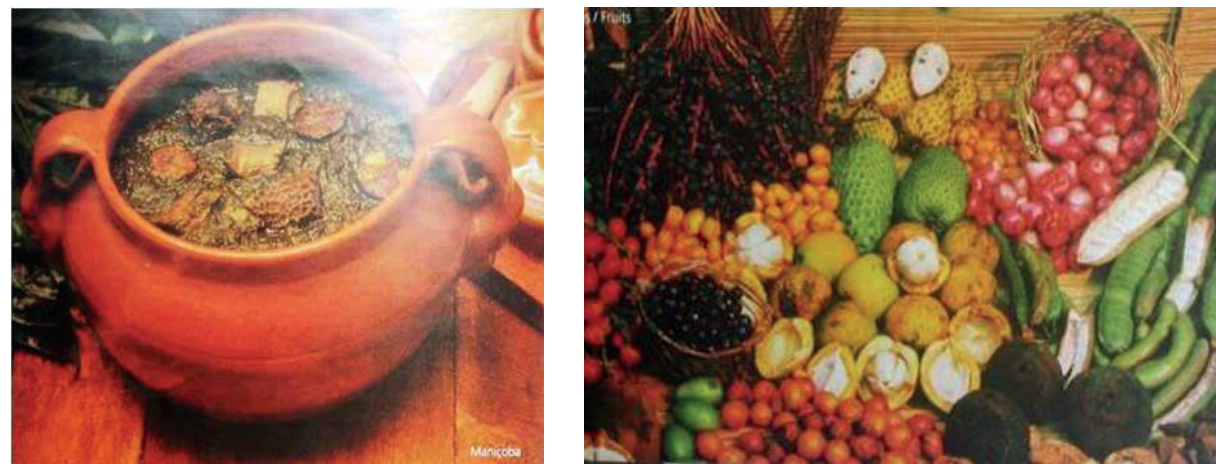

Fonte: Folder PARATUR, 2011.

A gastronomia é divulgada junto ao pacote cultural, do qual fazem parte a dança, o folclore e a música (Figura 13). O folder turístico organizado pela PARATUR é colorido, mede $21 \mathrm{~cm}$ x $30 \mathrm{~cm} \mathrm{e}$ foi impressa em papel couchê. A imagem da gastronomia é pouco expressiva, pois se mostrou o boi de máscara, ${ }^{6}$ deixando apenas três fotografias com pouco destaque para ressaltar a culinária paraense.

Os três pratos regionais que aparecem na segunda página são o açaí com peixe frito, a maniçoba e o tacacá. As fotografias estão bem enquadradas, com boa iluminação, possuem legendas e as iguarias estão centralizadas na composição. Entretanto, cada imagem mede $5 \mathrm{~cm}$ x $3,5 \mathrm{~cm}$, o que oferece pouca expressividade.

Apesar da qualidade do material, existe uma limitação na sua distribuição, pois o mesmo é destinado aos eventos de porte grande, às empresas, entre outros. De fato, poderia ser mais bem distribuído em locais que atingissem um número maior de turistas, como no Ver-o-Peso, em aeronaves e praças. Todavia, por ser uma revista de divulgação poderia, além de revelar os elementos gastronômicos, sugerir aos leitores os lugares para se degustar tais pratos.

Figura 13: Gastronomia e cultura

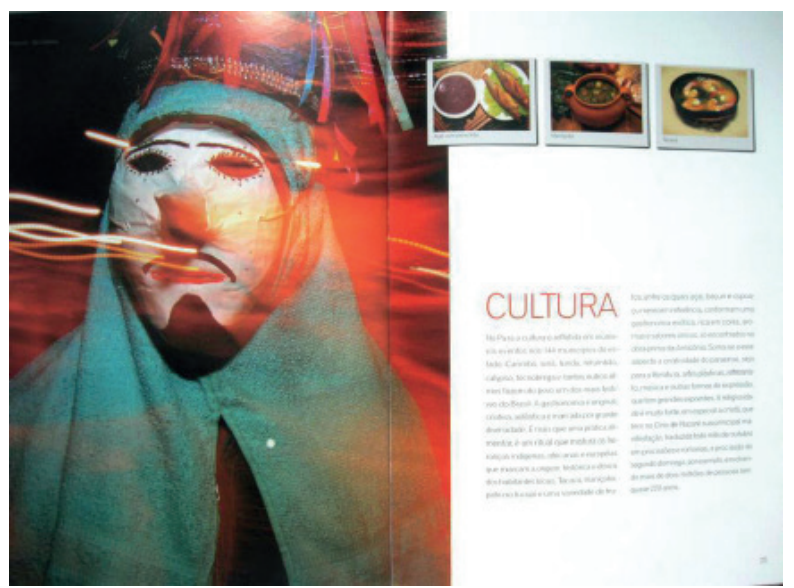

Fonte: Folder PARATUR, 2013.

Contraditoriamente, não existe uma política ativa de promoção voltada à gastronomia em Belém e no Pará. Tal realidade se encontra inserida em um planejamento como subsegmento da cultura, denominado Plano Ver-o-Pará. Com ele, objetiva-se colocar o Estado do Pará como líder em turismo na Amazônia, em 2020.

Perguntou-se, ainda, sobre o assunto a uma representante da Secretaria de Estado de Turismo do Pará (SETUR), a qual tem como função planejar o segmento. Segundo a diretora de produtos turísticos, a 
imagem da gastronomia se faz como uma representação e não como um atrativo. Também, ela informou que o segmento gastronômico não tem ganhado notoriedade na região, o que, aliás, é questionável.

A importância desses elementos para o planejamento da SETUR se encontra no legado dos antepassados, bem como no que permanece no saber do povo. Ela afirmou que existe uma procura relacionada à gastronomia paraense com o surgimento de festivais. Dentre esses, tem-se, desde o ano 2000, o festival "Ver-o-Peso da cozinha paraense". Assim como com a PARATUR, que trabalha com o Plano Ver-o-Pará, não existe uma política ativa voltada ao setor gastronômico. Mas esse é inserido no segmento cultura. PARATUR, SETUR e BELÉMTUR poderiam, além de apoiar eventos como o "Ver-o-Peso da cozinha paraense", incentivar a criação de outros que ocorram ao longo do ano e nos interiores também.

Assim, tais instituições priorizariam a gastronomia como atração principal, não apenas na capital, mas em outros municípios. Inclusive, seria importante ter o fomento até mesmo para a criação de circuitos gastronômicos. Nesta perspectiva, seriam contemplados os restaurantes que mais se destacam a cada ano. Desse modo, seriam destacados e divulgados em pontos estratégicos, como nos aeroportos e em hotéis.

Essa é uma tendência mundial como se depreende de muitos autores, a exemplo de Brien (2014), quando trata da gastronomia e sua conexão com o turismo em Singapura. Nesta cidade, tem-se:

"[...] a Conferência Mundial Gourmet [...] e a Exposição de Comidas do Pacífico, ambas atraindo profissionais da culinária internacional para trabalharem ao lado dos líderes locais. O Festival de Comidas de Singapura a cada julho é divulgado tanto para locais como para visitantes. [...] os singapurenses são orgulhosos de sua cultura e herança, assim que cada um se torna um embaixador proativo de sua cozinha" (Brien, 2014: S/pp).

Todavia, observa-se que essa é uma cidade que, há décadas, depende economicamente do turismo, embora essa associação entre gastronomia e turismo tenha-se tornado mais ampla a partir de 2011.

A possibilidade de existir uma política ativa para o setor gastronômico poderia proporcionar um norte para que houvesse uma promoção melhor da gastronomia. Isso pode ocorrer ante o potencial expressivo da cultura amazônica. E, ainda, contribuiria para que seus elementos fossem mais acessados por turistas e interessados na gastronomia da Amazônia por meio de materiais bem elaborados de divulgações periódicas, em sites relacionados ao tema, em empresas aéreas, entre outros.

A pesquisa qualitativa revelou que há uma preocupação maior das instituições públicas no que se refere à qualidade dos materiais em tais divulgações. Porém, ainda existe certa carência nos incentivos dessas promoções, principalmente no que concerne à distribuição e acessibilidade.

Mediante a promoção incipiente das empresas privadas e materiais de qualidade baixa, entende-se que o incentivo maior poderia ser iniciado pelas instituições públicas; isso poderá impulsionar um setor dotado de tanto valor simbólico para a região. Como afirmou Orico (1972), a marca da culinária paraense é a autenticidade, especialmente, pelas matérias-primas autóctones.

\section{Aspectos analíticos complementares a partir de estudo de caso}

Optou-se por um estudo de caso pelo fato de que este se caracteriza entre outros aspectos e segundo Yin (2010: 40), por “[...] beneficiar-se do desenvolvimento anterior das preposições teóricas para orientar a coleta e a análise de dados". Além disso, Yin (2010) afirma que o estudo de caso é uma investigação utilizada quando se quer compreender um fenômeno em profundidade, porém esse entendimento engloba importantes condições contextuais pertinentes ao estudo.

Fez-se este estudo de caso por meio de questionários aplicados aos turistas em dois restaurantes, "Point do Açaî" e "Lá em Casa", dois hotéis, "Tulip Inn Nazaré" e "Ecopousada Miriti" e o mercado Ver-o-Peso, famoso local turístico da cidade e ponto de encontro de feirantes e consumidores de peixe, frutas, ervas, entre outros produtos regionais. Por se ter quatro locais privados e com limitações de permanência para a aplicação da pesquisa, definiu-se pela aplicação de apenas 10 questionários para cada estabelecimento. No Ver-o-Peso, aplicou-se também 10 questionários.

$\mathrm{Na}$ realização do estudo de caso, constatou-se uma maior parcela do gênero masculino, com $52 \%$, e o gênero feminino com $48 \%$. Além disso, a maioria dos entrevistados se encontra acima de 45 anos, o equivalente a $44 \%$. O fato de eles possuírem idade superior a 45 anos pode sugerir que esse grupo seja mais focado nas divulgações para que possivelmente haja acesso a tais produtos. A segunda parcela maior está entre 26 e 35 anos, correspondendo a $22 \%$. Podem ser estudadas ainda quais são suas aspirações quanto à qualidade de ofertas e serviços.

Os sujeitos da pesquisa foram organizados em dois grupos: turistas nacionais e internacionais (Gráfico 1) Os turistas nacionais representam 56\% e os internacionais 30\%. Os dados mostram que os 
brasileiros estão viajando para o norte em busca de outros atrativos e não apenas para eventos como o Círio $^{7}$. Questiona-se, portanto: será que os produtos culinários também são alvos de tal busca ou, ainda, há a predominância de sol e praia?

Gráfico 1. Origem dos turistas

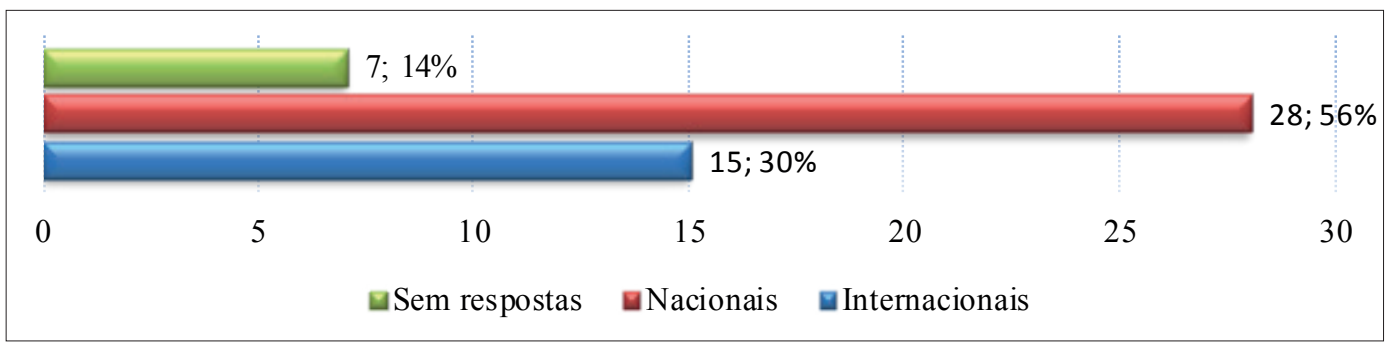

Fonte: Pesquisa de Campo - Belém/ PA, 2012: 2013.

Questionou-se ainda sobre a procedência dos turistas nacionais, sendo que a maioria deles é oriunda do Estado de São Paulo (39\%). Em seguida, evidenciam-se os turistas vindos de Minas Gerais (17\%), enquanto que apenas uma pessoa procede do Ceará (3\%). O fato de a maioria ser da região sudeste coloca em evidência a diferença de poder aquisitivo existente nas regiões do Brasil. Ademais, isso revela que estes Estados brasileiros garantem uma incidência maior de pessoas que viajam se comparado à região nordestina, com índice menor de poder aquisitivo.

Identificou-se que os turistas internacionais procedem da Alemanha e Itália, num percentual de 20\%, e da Holanda com 13\%. O restante vem de países como o Chile, França, Grécia, Inglaterra, Irlanda, Israel e Uruguai, com 7\% cada. Os dados apontam para uma diversificação de nacionalidades e sugerem que muitos países podem estar divulgando certos atrativos da região.

Com relação à escolaridade dos entrevistados (Gráfico 2), a maioria possui formação superior completa (66\%), seguido de $24 \%$ dos que possuem o $2^{\circ}$ grau completo, $6 \%$ têm superior incompleto e $4 \%$ apresentam o $2^{\circ}$ grau incompleto. As informações do gráfico que se segue mostram que a maioria dos turistas possui nível superior completo, portanto, requer qualidade maior dos produtos. Assim, a divulgação das imagens pode ser elaborada, pensando em termos mercadológicos, visando este público que, possivelmente, é atraído por materiais bem elaborados.

\section{Gráfico 2: Grau de escolaridade}

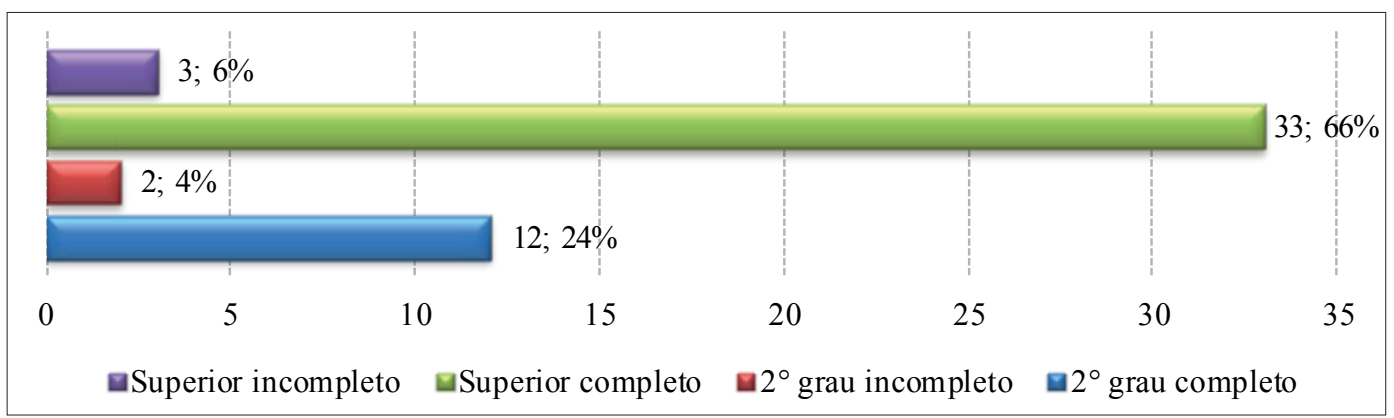

Fonte: Pesquisa de Campo - Belém/ PA, 2012: 2013.

O motivo pelo qual os turistas escolheram a Belém foi também abordado pelos questionários. Dos 50 entrevistados, $52 \%$ foram motivados por lazer, $28 \%$ por trabalho, $6 \%$ por congresso, e $2 \%$ vieram em função de visita a amigos. As informações deste gráfico são relevantes para os profissionais que desejam trabalhar com vista à permanência dos visitantes na cidade, de um modo que possa atingir tal público, por meio de intervenções nos locais que esses estejam visitando, como os pontos turísticos, universidades ou empresas. 
A maioria dos entrevistados esteve na cidade pela primeira vez, o que corresponde a $52 \%$ deles. Esse percentual veio seguido de $14 \%$, refletindo os que estiveram pela segunda vez. Os demais: $6 \%$, pela terceira vez, $4 \%$, pela quarta vez e $18 \%$ já haviam visitado a cidade por mais de cinco vezes.

Os dados podem auxiliar nas estratégias que atingirão tanto as pessoas que vêm pela primeira vez como as que já conhecem o local, pensando em inovações nas divulgações e em diversificar as atrações, tanto para quem já as conhece, dando-lhes novas opções, quanto para aqueles que ainda não as conhecem, oferecendo-lhes alternativas diversas de entretenimento.

No Gráfico 3, mostra-se a quantidade de pessoas que acessaram as imagens da gastronomia paraense, antes de vir ao Pará. 56\% não tiveram acesso, enquanto que $42 \%$ responderam que sim e $2 \%$ não respondeu à pergunta. A partir desses dados, vê-se que a maioria dos turistas ainda não está tendo acesso a esse tipo de informação visual. Como se depreende de Simonian (2007), isso aponta para uma falha possível na divulgação dessas imagens já que as mesmas podem mostrar muito dos elementos culturais da região, pois as fotografias possuem, em si, um poder cultural e histórico.

Gráfico 3: Teve acesso a fotografia da culinária paraense antes de vir ao Pará

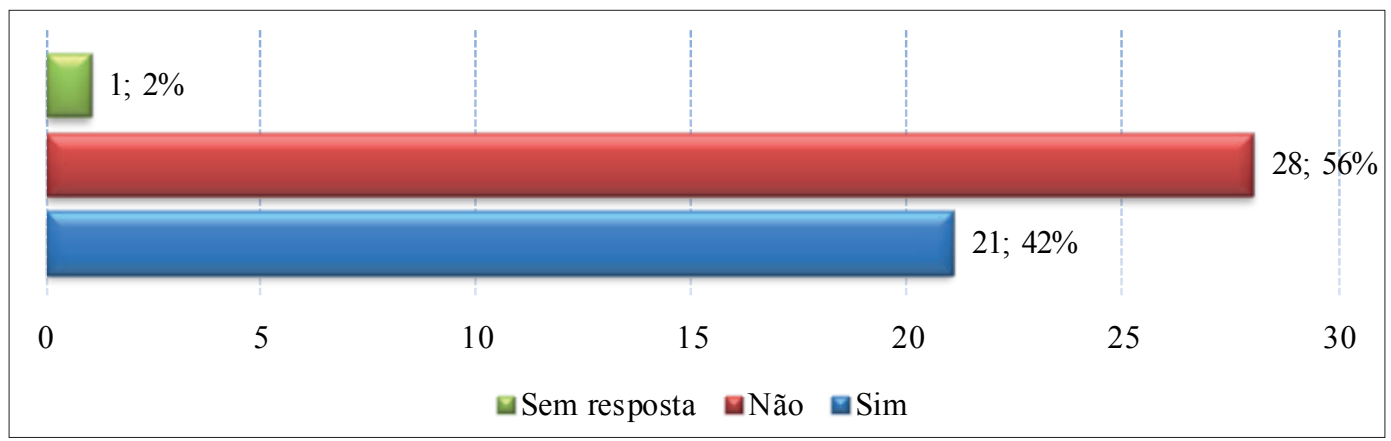

Fonte: Pesquisa de Campo - Belém/ PA, 2012: 2013.

Acerca do meio de comunicação utilizado pelos entrevistados que tiveram acesso às imagens gastronômicas, constatou-se que $61 \%$ valeram-se da internet. Outros $9 \%$ afirmaram haver acessado todos os meios, principalmente fotografias, e o restante, $4 \%$, cada meio. Diante do fato de a internet representar o meio mais acessado, conclui-se que é necessário inovar a apresentação desses produtos, para que não se repitam e, desse modo, atrair mais interessados.

Ainda, poderiam ser criadas estratégias para outros meios de comunicação, a fim de que atinjam públicos diversos. Um exemplo a ser considerado diz respeito aos que lêem revistas e jornais. No entanto, sabe-se que não está sendo feito o uso e tampouco o aproveitamento dos meios de comunicação para a divulgação de tais imagens.

Finalmente, indagou-se acerca da influência da imagem (Gráfico 4) sobre a escolha do local. A diferença foi de $14 \%$. Isso porque $57 \%$ afirmaram que as imagens não influenciaram na escolha do local, enquanto que os $43 \%$ restantes asseveraram que houve influência. A pouca influência de tais imagens pode estar relacionada à qualidade baixa das divulgações, bem como das imagens que estão sendo produzidas.

Gráfico 4: O acesso à fotografia influenciou na sua escolha?

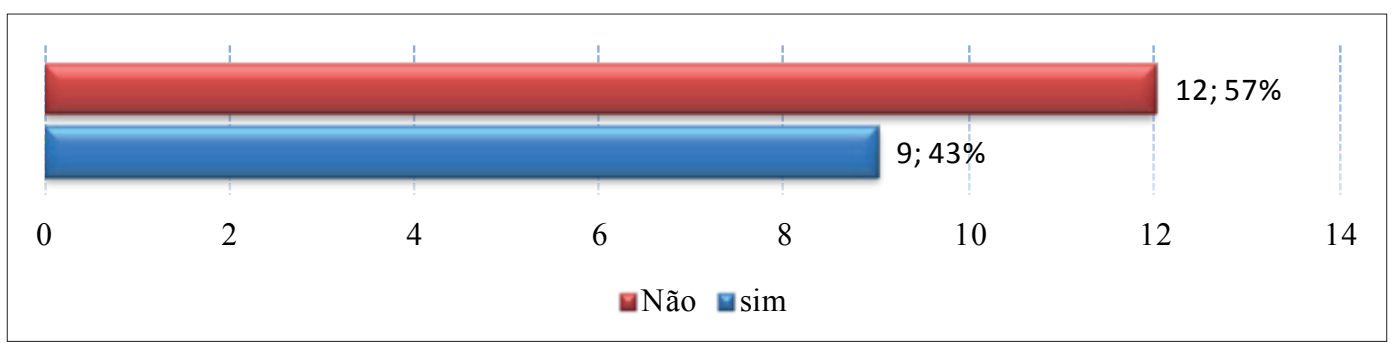

Fonte: Pesquisa de Campo - Belém/ PA, 2012: 2013. 
Isso resulta em atratividade escassa. Logo, percebe-se que as imagens não são veiculadas de maneira que possam atrair um número maior de visitantes para tornar a gastronomia mais conhecida e valorizada pelos turistas. Uma imagem turística da gastronomia pode ser construída com a finalidade de atrair o olhar do visitante, a partir de recursos distintos, como traços culturais, hábitos da população local e as influências ocorridas ao longo da história.

Além disso, segundo Hadlich (2008) a fotografia turística está condicionada a uma imagem boa. Portanto, é necessária a inclusão de meios que despertem a curiosidade e o desejo de consumir, por gostos diferentes. Para isso, são considerados elementos, como cores vivas, iluminação e maior destaque em materiais impressos.

O fato de não ter havido um número maior de turistas influenciados por imagens gastronômicas põe em questionamento a divulgação da gastronomia paraense por meio do uso de fotografias. Entende-se que, para um conhecimento e uma valorização mais apurada da culinária local por visitantes ou interessados em conhecer a região, necessita-se promover a gastronomia paraense. E as imagens são essenciais neste aspecto, de modo que possibilitam a transmissão de peculiaridades da região.

\section{Conclusão}

Ao partir da ideia de que o turismo é um segmento socioeconômico e que proporciona experiências variadas aos atores envolvidos (Panosso Netto, 2005), percebeu-se que a fotografia passou a integrar cada vez mais este cenário. E, principalmente, como um registro visual para vender destinos e conteúdos.

Houve dificuldade em encontrar quantidade suficiente de material bibliográfico para a análise de imagens turísticas mais voltadas à imagem gastronômica. Portanto buscaram-se fundamentos em teóricos que analisam a imagem via outras percepções, como a artística (Gombrich, 1965 apud JACQUES, 1993). Junto com Simonian (2007), este autor foi fundamental.

Nesse sentido, surgiram questionamentos relacionados à circulação de imagens fotográficas da gastronomia paraense, uma vez que a alimentação é um elemento cultural (Silva, 2005), além de representar uma cultura material diretamente ligada à subsistência de um segmento social. Segundo Coelho Neto e Urias (2011), constatou-se que uma das maneiras para se aproveitar o potencial da gastronomia enquanto atrativo turístico é compreender de que modo circula a informação a respeito desta.

A partir do resultado da pesquisa, observou-se que empresas e instituições públicas não exploram as imagens fotográficas para atrair turistas. Tampouco, atentam para uma distribuição eficaz do pouco material que se teve acesso. Mas acredita-se que é necessário priorizar certos aspectos para que a divulgação da gastronomia seja mais bem desenvolvida.

Logo, há que aumentar a articulação entre instituições públicas e empresas privadas, além de incentivar e melhorar a elaboração de imagens nos meios como a internet, revistas, jornais, materiais de divulgação em aeronaves etc. Necessita-se propor imagens que instiguem "desejos" e "possibilidades investigativas", que mostrem símbolos e expressividades. E, quem sabe, também, tornar o Pará um local de conexão entre gastronomia e turismo, sem esquecer a participação da população local, como já alcançado em Cingapura (Brien, 2014), uma vez que esta é uma tendência mundial.

Compreende-se que a imagem da gastronomia paraense revela traços do legado cultural da região. Isto pode despertar interesse turístico a quem puder acessar a tais imagens. Assim, cabe às instituições públicas e empresas privadas incentivarem o turismo no Pará e promoverem estudos e pesquisas para a utilização de imagens relacionadas à gastronomia.

Se assim for, é provável que, em um blogue ou revista, uma fotografia do tacacá venha a despertar no turista o interesse por um destino. Ou mesmo efetivar um contato com a cidade de Belém do Pará. Ao aqui chegar, ou já estando, poderá desfrutar o sabor do jambu, camarões ensopados pelo tucupi ou um sorvete de frutas regionais, numa tarde belenense ensolarada.

\section{Bibliografia}

Acunã, Cristóbal.

1941. "Novo descobrimento do grande rio das Amazonas". Em Leitão, C. M. (Org.), Descobrimentos do rio das Amazonas (pp. 125-286). São Paulo: Cia. Editora Nacional.

Brien, Donna L.

2014. "A taste of Singapure food writing and culinary tourism". Journal of Media and Culture, 17 (1): S/pp. Disponível em: http://journalmedia-culture.org.au/index.php/mcjournal/article/view/767. Acesso em: 16/06/2016. 
Coelho Neto, Ernani e Urias, Leandro.

2011. "Personalidade gastronômica e destinos turísticos: avaliação dos canais de comunicação na projeção dos atrativos gastronômicos no nordeste brasileiro". Turismo em análise, 22(2): 322-340. Disponível em: http://www.revistasusp.sibi.usp.br/pdf/rta/v22n2/05.pdf. Acesso em: 10/05/2012.

Cohen, Erik.

2012. „Globalization, global crises and tourism“. Tourism, recreation and research, 37: 103-111. Disponível em: http://www.trrworld.org/pdfs/64k11qti3643r19kv16evi3242j19ro.pdf. Acesso em: 31/05/2016.

Crotts, John S. e Kivela, Jaksa.

2006. "Tourism and gastronomy: Gastronomy's influence on how tourists experience a destination". Journal of hospitality and tourism research, 30: 354-377. Disponível em: file:///C:/Users/C\%C3\%A1ssia\%20 Mareco/Downloads/Journal\%20of\%20Hospitality\%20\&\%20Tourism\%20Research-2006-Kivela-354-77. pdf. Acesso em: 05/05/2016.

Dropa, Ana. F. N., Trzaskos, Luana e Baum, Jessica.

2011. "A imagem fotográfica como recurso de valorização cultural e seu uso pelo turismo: um estudo de caso da colônia Sutil”. ENPPEX 7. Disponível em: http://www.fecilcam.br/anais/vii_enppex/PDF/ turismo/ 03-turismo.pdf. Acesso em: 14/04/2012.

Fagliari, Gabriele S.

2005. Turismo e alimentação: análises introdutórias. São Paulo: Roca.

Ferreira, Alexandre R.

1974. Viagem filosófica pelas Capitanias do Grão Pará, Rio Negro, Mato Grosso e Cuiabá: zoologia e botânica. Rio de Janeiro: Cons. Fed. de Cultura.

Hadlich, Donaldo.

2008. "O olhar fotográfico aplicado ao turismo". Em Cândido, Luciane A. (Org.), Turismo: múltiplas abordagens (pp. 105-115). Novo Hamburgo: FEEVALE. Disponível em: http://aplicweb.feevale.br/ site/files/documentos/pdf/28268.pdf\#page=105. Acesso em: 01/06/2012.

Jacques, Aumont.

1993. "A imagem". Em Abreu, E. S. e Santoro, C. C. (Tradutores). Papirus, Campinas.

Lisboa, Aldo e Simonian, Ligia T. L.

2011. "Gastronomia internacional e hábitos alimentares amazônicos: expansão e transformação". Zinak: Cuadernos de Antropologia-Etnografia, 34: 337-351. Disponível em: http://www.euskomedia.org/ PDFAnlt/zainak/34/34337351.pdf. Acesso em: 16/05/2012.

Maués, Maria A. M. e Maués, R. Heraldo

1980. O folclore da alimentação: tabus alimentares da Amazônia (um estudo de caso numa população do litoral paraense). Belém: Falangola.

Monterrubio, Carlos. J. e Mendoza-Ontiveros, M. Marivel.

2014. "Tourism and the demonstration effect: empirical evidence". Tourism and management studies, 10: 97-103. Disponível em: http://tmstudies.net/index.php/ectms/article/view/653/1166. Acesso em: 20/05/2016.

Murrieta, Ruy S. S.

2001. "Dialética do sabor: alimentação, ecologia e vida cotidiana em comunidades ribeirinhas da ilha de Ituqui, Baixo Amazonas, Pará”. Revista de antropologia, 2: 39-88. Disponível em: http://www.scielo. br/scielo.php?pid=S0034-77012001000200002\&script=sci_arttext. Acesso em: 05/08/2012.

Orico, Osvaldo.

1972. "Cozinha amazônica: uma autobiografia da coleção amazônica”. Belém: UFPA.

Panosso Netto, Alexandre.

2005. Filosofia do turismo: teoria e epistemologia. São Paulo: Aleph.

Ribeiro, Anna C.

2012. "E foi assim que tudo começou. Orgulho do Pará-Gastronomia". Jornal Diário do Pará, 2-3.

Santos Júnior, Aldemir P. e Santos, Aldenyra C. F.

2007. "Arte e turismo: a fotografia como ferramenta de trabalho do turismólogo contemporâneo".

Revista eletrônica Aboré3, Escola Superior de Artes e Turismo. Disponível em: http://www.revistas. uea.edu.br/old/abore/artigos/artigos_3/Aldemir\%20Pereira\%20dos\%20Santos\%20Junior.pdf. Acesso em: 20/03/2012.

Silva, Paula P.

2005. "Farinha, feijão e carne-seca: um tripé culinário no Brasil colonial". São Paulo: SENAC. 
Simonian, Ligia T. L.

2011. "Photographic exhibit small kitchens". Em Mayer-Husmann, Ulrich (curator). Wiesbaden, Germany: Bellevue-Saal.

Simonian, Ligia T. L.

2007. "Uma relação que se amplia: fotografia e ciência sobre e na Amazônia" (pp. 15-52). Em Kawhage, Cláudia e Ruggeri, Sandro. Imagem e pesquisa na Amazônia: ferramentas de compreensão da realidade. Belém: Mus. Par. Emílio Goeldi.

Yin, Robert K.

2010. Estudo de caso: Planejamento e métodos. Porto Alegre: Bookman, 2010.

\section{Notas}

Feijão tropeiro é prato composto de feijão misturado à farinha de mandioca, torresmo, linguiça, ovos, cebola e temperos.

2 Vendedora de tacacá. Artista: Antonieta Santos Feio. Tela. Belém, 1937. Disponível em: http://saavedramusicachibeepoesia. blogspot.com.br/2011/04/paraenses-notaveis-antonia santos-feio.html. Acesso em: 20/07/2013.

3 AAmazônia brasileira consiste nos estados Amazonas, Acre, Amapá, Maranhão, Mato Grosso, Rondônia, Roraima e Pará.

4 O uso do termo cliente está relacionado ao sentido comercial.

5 Material impresso com dimensões reduzidas (A5 ou menor) para distribuição ampla, com custo baixo de emissão.

6 Dança folclórica de São Caetano de Odivelas (Pará).

7 Festa religiosa católica de porte grande, que ocorre todo ano em outubro, em Belém-Pará. 